ANUVA Volume 1 (1): 11-18, 2017

Copyright C2017, ISSN: 2598-3040 online

Available Online at: http://ejournal.undip.ac.id/index.php/anuva

\title{
Pengaruh Penggunaan Teknologi Tepat Guna dalam Meningkatkan Produktivitas UKM Batik Tulis di Kampung Batik Kauman Kota Pekalongan
}

\author{
Ana Irhandayaningsih ${ }^{1 *}$ \\ ${ }^{\text {I} P r o g r a m ~ S t u d i ~ I l m u ~ P e r p u s t a k a a n, ~ F a k u l t a s ~ I l m u ~ B u d a y a, ~ U n i v e r s i t a s ~ D i p o n e g o r o, ~}$ \\ Jl. Prof. Soedarto, SH, Kampus Undip Tembalang, Semarang, Indonesia \\ *) Korespondensi: irhandayaningsih@gmail.com
}

\begin{abstract}
This study aims to determine the effect of the use of technology in improving the productivity of SME Batik Mas and Batik Nulaba through improvement of production, marketing, and management processes. The Technology that is applied are : batik dye feeder machine that will be applied in SME Batik Mas, integrated digital marketing technique assistance and SME mini studio implementation to improve the quality of product photos in SME Batik Nulaba, ergonomic workshop and work safety in SME Batik Mas, Search Engine Optimation technical assistance to improve online visitors in SME Batik Nulaba, as well as mentoring customer relationship management techniques in SMEs Batik Mas.Impacts generated for SME Batik Mas is the number of workers involved to be reduced, the time of the coloring process decreases, and the work posture staining improved. The resulting impact for SME Batik Nulaba is the presence of online catalogs and more and more marketing reach, and the number of sales increases.
\end{abstract}

Keywords: Batik SME, technology, productivity improvement

\begin{abstract}
Abstrak
Penelitian ini bertujuan untuk mengetahui pengaruh penggunaan teknologi tepat guna dalam peningkatan produktivitas UKM Batik Mas dan Batik Nulaba melalui perbaikan proses produksi, pemasaran, dan manajemen. Teknologi tepat guna yang diterpatkan adalah penerapan mesin feeder pewarnaan batik yang akan diaplikasikan di UKM Batik Mas, pendampingan teknik integrated digital marketing serta penerapan mini studio skala UKM untuk meningkatkan kualitas foto produk di UKM Batik Nulaba, workshop ergonomic dan keselamatan kerja di UKM Batik Mas, pendampingan teknik Search Engine Optimation untuk meningkatkan pengunjung online di UKM Batik Nulaba, serta pendampingan teknik customer relationship management di UKM Batik Mas. Dampak yang dihasilkan bagi UKM Batik Mas adalah jumlah tenaga kerja yang terlibat menjadi berkurang, waktu proses pewarnaan berkurang, dan postur kerja pewarnaan mengalami perbaikan. Dampak yang dihasilkan bagi UKM Batik Nulaba adalah adanya katalog online dan jangkauan pemasaran semakin banyak, serta jumlah penjualan meningkat.
\end{abstract}

Kata kunci: UKM Batik, teknologi tepat guna, peningkatan produktivitas

\section{Pendahuluan}

Kelurahan Kauman yang berlokasi di Kecamatan Pekalongan Timur Kota Pekalongan Provinsi Jawa Tengah, memiliki luas wilayah lebih kurang $8 \mathrm{~km}$ persegi dan dibagi menjadi $16 \mathrm{RW}$. Jumlah penduduk Kauman mencapai 14.000 jiwa, dengan kepadatan lebih dari 1.500 jiwa per km persegi. Berdasarkan data tahun 2015, jumlah angkatan kerja di kelurahan ini mencapai sekitar 88.312 jiwa, dan sebagian besar bekerja di sektor sekunder seperti kerajinan batik, disusul sektor tersier seperti perdagangan dan jasa pekerjaan di swasta. Kauman juga memiliki kekayaan seni budaya, karena merupakan lokasi akulturasi kebudayaan Jawa Arab dan Tiongkok. 
UKM pertama yang menjadi obyek penelitian adalah Batik Mas. Batik Mas merupakan salah satu home industry pengrajin batik di Kampung Batik Kauman Pekalongan. Batik Mas berada di RT 3 RW 4 kawasan Kampung Batik Kauman, dimana di lokasi ini terdapat rumah batik (workshop) di bagian depan dan rumah produksi di bagian belakang. Usaha ini telah didirikan sejak dekade 1960 dan pemilik saat ini, Bapak H. Hisyam, merupakan pengelola generasi ketiga. Batik Mas memproduksi batik dari bahan kain sutera, tenun bukan mesin, dan katun. Motif yang diproduksi adalah motif pesisiran, jlamprang (khas Pekalongan), encim, buketan dan motif baru lainnya.

Bapak H. Hisyam selaku pemilik UKM Batik Mas, mengungkapkan hambatan dalam produksi, yaitu pada bagian pewarnaan kain batik dengan ukuran lebih dari $2.5 \mathrm{~m}$ (panjang). Proses pewarnaan kain panjang ini menghadapi kesulitan tersendiri, karena warna menjadi tidak rata dan zat warna yang digunakan jadi lebih boros jika dibandingkan dengan kain dengan ukuran 1 yard $(90 \mathrm{~cm})$ maupun ukuran 1.3m. Apabila ada teknologi yang dapat diaplikasikan, Bapak H. Hisyam mengungkapkan keinginannya untuk memiliki alat bantu bagi pekerja dalam melakukan pewarnaan kain batik berukuran panjang, agar warna dapat merata serta efisien baik dalam hal penggunaan bahan baku, biaya, maupun tenaga.

UKM pertama yang menjadi obyek penelitian adalah Batik Nulaba, yang juga merupakan salah satu home industry di bidang kerajinan batik dan berlokasi di Kampung Batik Kauman Pekalongan. Batik Nulaba berada di RT 12 RW 3 kawasan Kampung Batik Kauman. Usaha ini didirikan pada 2013 oleh H Fathurrachman Noor. Batik Nulaba memproduksi batik dari bahan kain tenun bukan mesin, katun, dan dobby. Motif yang diproduksi didominasi oleh pesisiran kontemporer dan motif tiga negeri yang telah dimodifikasi. Sebagai UKM yang baru berdiri, Batik Nulaba berusaha mengedepankan harga harga murah dengan variasi warna yang beragam.

Sebagai UKM yang baru berumur tiga tahun, Batik Nulaba belum memiliki pangsa pasar yang besar dan belum memiliki banyak pelanggan tetap. Sebagian besar pembeli datang langsung ke toko Batik Nulaba di kawasan Kampung Batik Kauman, dan sebagian melakukan pembelian jarak jauh melalui media online. Meskipun belum memiliki toko online yang memadai, Batik Nulaba telah menerapkan pemasaran digital. Bahkan setiap bulan, Batik Nulaba menerima pesanan dari pelanggan yang berasal dari berbagai kota di Pulau Jawa seperti Jakarta, Blitar, Malang, Surabaya, Semarang. Cara pemasarannya masih secara konvensional. Para pelanggan yang pernah berbelanja di toko Batik Nulaba akan menghubungi melalui BBM ataupun Whatsapp. Kemudian pegawai toko dari Batik Nulaba akan mengirimkan foto produk kepada calon pembeli secara spontan. Tidak ada persiapan dan sentuhan artistik pada foto produk tersebut. Begitu juga dengan katalog online, yang masih belum dimiliki oleh Batik Nulaba. H Fathurrachman Noor sebagai pemilik Batik Nulaba, mengakui hal tersebut sebagai kekurangan. Pemiliki Batik Nulaba juga menyatakan keinginannya untuk memiliki toko online, memiliki katalog online yang menarik, dan mengelola pemasaran digital secara professional untuk meningkatkan pangsa pasar dan penjualan. Namun, Batik Nulaba menghadapi keterbatasan pengetahuan dan sumberdaya manusia, sehingga mengharapkan adanya pendampingan untuk mewujudkan 
pemasaran digital. Permasalahan lain adalah dalam hal pembukuan. Sama seperti kasus Batik Mas, Batik Nulaba juga belum memiliki SOP pembukuan yang baku sesuai kaidah komputerisasi akuntansi.

\section{Metode Penelitian}

Metode Kualitatif yang dilakukan bertahap terdiri dari: 1) teknik pengumpulan data menggunakan participant observation (peran serta) dan in depth interview (wawancara mendalam) kepada dua UKM yang menjadi obyek penelitian. Penelitian kualitatif bersifat holistik dan lebih menekankan pada proses. 2) Stainback (2003) menekankan ciri kualitatif pada partisipasi intensif, rekaman, dan penulisan serta proses dokumentasi secara bertahap dan analisis secara hati-hati dari dokumentasi yang ada serta laporan atas interpretasi suatu objek dan kedalaman interview. Dokumentasi dan seluruh partisipasi dalam riset ini direkam dalam bentuk tulisan dan gambar.

\section{Hasil dan Pembahasan}

Alat feeder yang diimplementasikan di UKM Batik Mas, bekerja dengan mekanisme sebagai berikut :

i. Operator mengambil kain yang telah direndam dalam air (kain basah).

ii. Operator mengaitkan salah satu ujung kain ke penjepit di tongkat penyangga kain 1.

iii. Bagian tengah kain (yang ada didalam bak) ditahan dengan menggunakan tongkat penahan yang ada didalam bak.

iv. Ujung kain yang lain dikaitkan pada penjepit di tongkat penyangga kain 2.

v. Operator menarik dan mengulur tongkat kendali agar tongkat penyangga kain bergerak naik turun secara bergantian.

vi. Setelah kain selesai dicelupkan, kain dilepas dari tongkat penyangga kain, kemudian ditiriskan pada tiang tirisan. Setelah kain selesai ditiriskan, dapat dilanjutkan ke proses berikutnya.

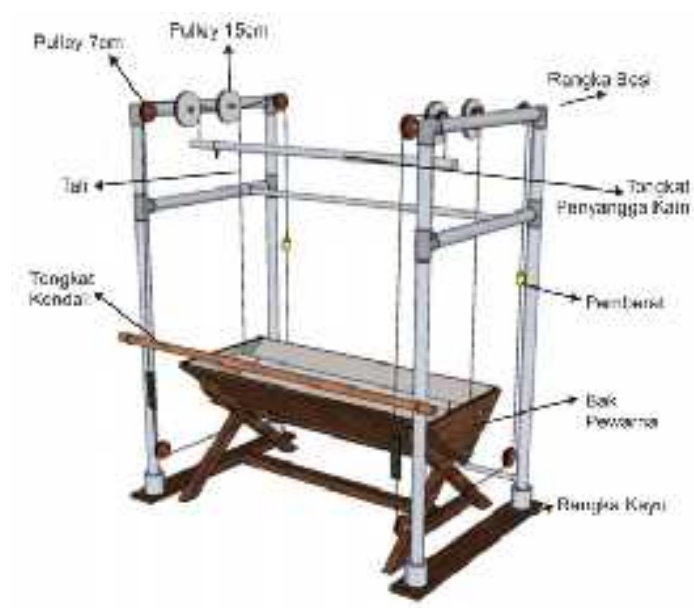

Gambar 1. Detail Desain Alat 


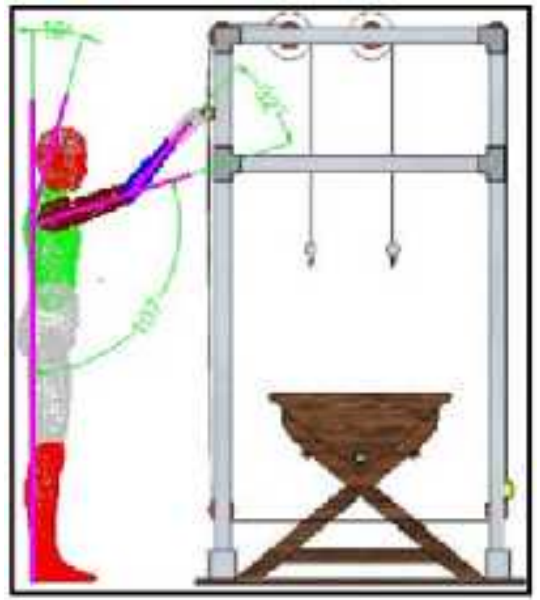

Gambar 2. Ilustrasi pengoperasian

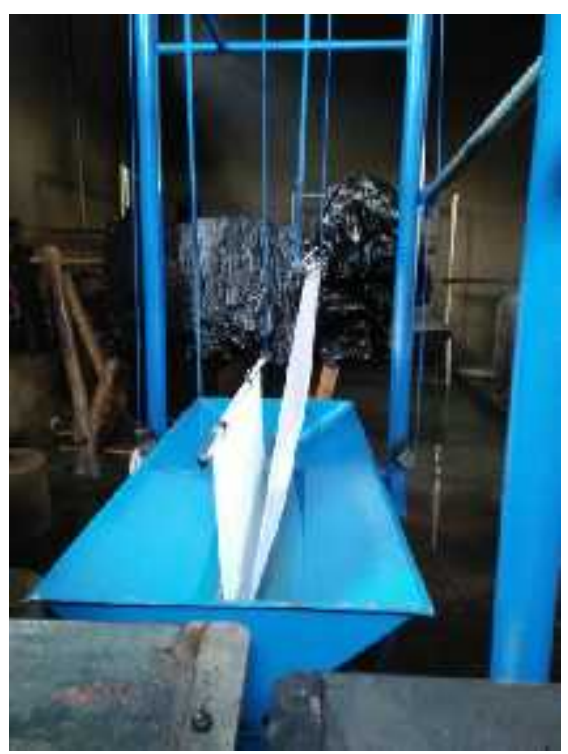

Gambar 3. Implementasi alat

Mini studio yang diimplementasikan di UKM Batik Nulaba terdiri dari lighting dan white background. Berikut adalah tampilan mini studio yang diimplementasikan. 


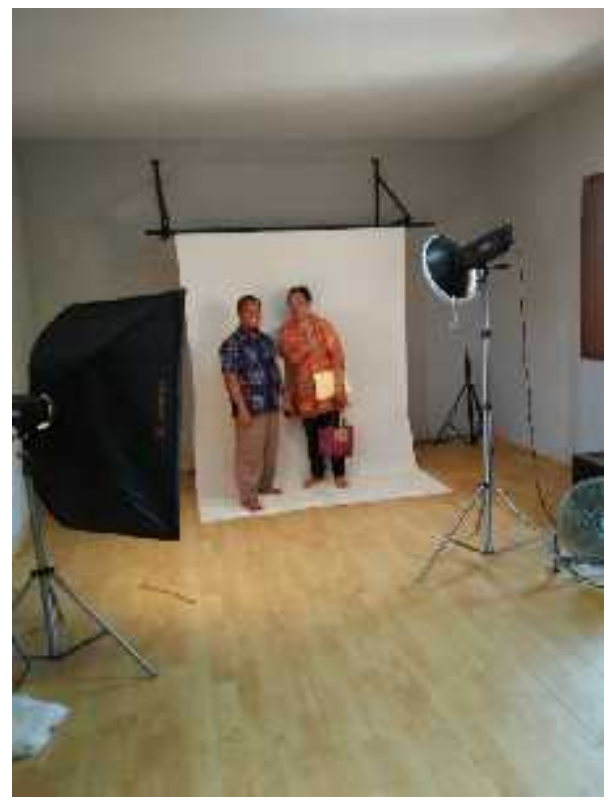

Gambar 4. Implementasi mini studio

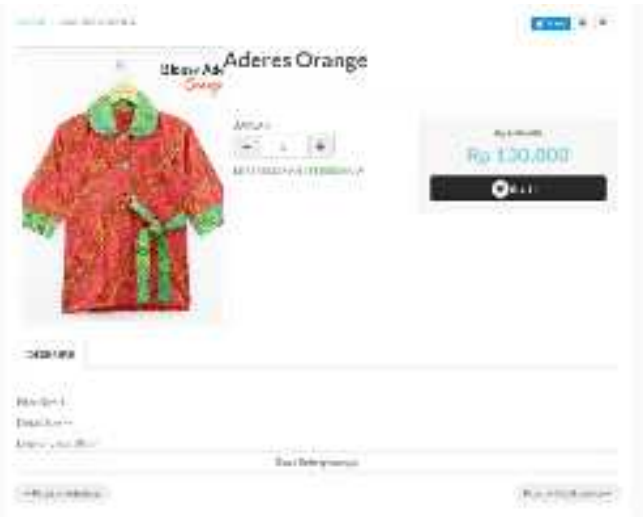

Gambar 5. Tampilan katalog online

Berdasarkan pengamatan dan wawancara dengan pemilik dan pegawai UKM Batik Mas mengenai dampak penggunaan alat pewarna batik yang dihasilkan dalam PENELITIAN ini, hasilnya adalah sebagai berikut :

\begin{tabular}{lcc}
\hline \multicolumn{1}{c}{ Aspek } & Sebelum penerapan & Setelah penerapan \\
\hline Jumlah Tenaga Kerja & 2 orang & 1 orang \\
Waktu proses & $10-15$ menit menit & $12-15$ menit \\
Obat batik & 10 gram per 20 kain & 10 gram per 20 kain \\
Variasi gerakan & $\begin{array}{c}\text { Membungkuk kemudian } \\
\text { berdiri (berulang) } \\
\text { Standar kualitas premium }\end{array}$ & Berdiri dengan mengayun-kan lengan \\
Kualitas hasil & & Standar kualitas premium
\end{tabular}


Berdasarkan pengamatan dan wawancara dengan pemilik dan pegawai UKM Batik Nulaba mengenai dampak penggunaan mini studio dan katalog online yang dihasilkan dalam penelitian ini, hasilnya adalah sebagai berikut :

\begin{tabular}{lcl}
\hline \multicolumn{1}{c}{ Aspek } & Sebelum penerapan & \multicolumn{1}{c}{ Setelah penerapan } \\
\hline Jenis pemasaran & Offline & \multicolumn{1}{c}{ Offline dan Online } \\
Foto produk & Belum Ada & \multicolumn{1}{c}{ Ada } \\
Kualitas foto produk & Belum Ada Foto Produk & $\begin{array}{l}\text { Setara dengan brand fashion ternama } \\
\text { Pembeli ada yang berasal dari } \\
\text { Sumatera, Kalimantan, Sulawesi, } \\
\text { Bangkauan pemasaran }\end{array}$ \\
$\begin{array}{l}\text { Jumlah penjualan secara } \\
\text { online }\end{array}$ & Sekitar Pekalongan & Rata-rata 200 item per bulan \\
\hline
\end{tabular}

\section{Simpulan}

Teknologi tepat guna yang diimplementasikan antara lain : (i) penerapan alat feeder pewarnaan batik di UKM Batik Mas, (ii) pelatihan penggunaan alat beserta workshop ergonomic dan keselamatan kerja di UKM Batik Mas, (iii) penerapan integrated digital marketing bagi UKM Batik Nulaba, (iv) penerapan mini studio bagi UKM Batik Nulaba, dan (v) workshop penggunaan integrated digital marketing untuk meningkatkan pengunjung online di UKM Batik Nulaba.

Dampak yang dihasilkan bagi UKM Batik Mas adalah jumlah tenaga kerja yang terlibat menjadi berkurang, waktu proses pewarnaan berkurang, dan postur kerja pewarnaan mengalami perbaikan. Dampak yang dihasilkan bagi UKM Batik Nulaba adalah adanya katalog online dan jangkauan pemasaran semakin banyak, serta jumlah penjualan meningkat.

\section{Daftar Pustaka}

Ahmad, M. (2007). Pembangunan Berkelanjutan Refleksi Singkat dan Langkah Ke Depan. Balikpapan: ISEI.

Aswicahyono, H. (2007). Membangun Daya Saing Industri. Balikpapan: ISEI.

Bachrudin, A., dan Tobing, L. H. (2003). Analisis Data Untuk Penelitian Survei. Bandung: Universitas Padjadjaran.

Bruton, G. D., White, M. A. (2006). The management of Technology and Innovation: A Strategic Approach. Thomson. 
Chaundhury, Abhijit, Kuilboer, Jean-Pierre (2002). E-business and E-commerce Infrastructure : Technologies Supporting the E-business Initiative. USA: McGraw-Hill.

Chittor, R and Das, R. (2007). Professionalization of Management and Succession performance-a vital linkage, Family Business Review, Vol.20 No 1. Pp 65-79.

Dewanti, R. (2010). Membangun Daya Saing Potensi Daerah Melalui UKM, laporan riset 2010. Jakarta: Binus University.

Greenstein, Marilyn, Feinman, T, M. (2000). Electronic Commerce: Security, Risk Management and Control. International Edition. McGraw-Hill.

Haag, S., Cummings, M., McCubrey, D. J. (2005). Management information systems for the information age. NY: McGraw-Hill/Irwin.

Heizer, J., dan Render. (2008). Operation Management. Jilid 2. Jakarta: Salemba Empat.

Jurnal Ekonomi \& Kemasyarakatan. (2005). Entrepreneurship Keluar dari Jeratan Bangsa Kuli. Equilibrium Vol 2. Jakarta.

Karimi, S. (2007). Reformasi Pelayanan Publik Untuk Penguatan Pembangunan Ekonomi. Balikpapan:ISEI

Kotler, P., Armstrong, G. (2004). Principles of Marketing, Tenth Edition. New Jersey: Pearson Prentice Hall.

Man, T.W.Y., lau, T, and chan, K. F. (2002). the Competitiveness of Small and medium enterprises: A conceptualization with focus on entrepreneurial competences. Journal of business Venturing 17 (2): 123-142.

Mathiassen, Lars, et.al. (2000). Object Oriented Analysis \& Design. Amerika. Aps., Denmark: Marko Publishing Prentice Hall.

Mcleod, R, Jr., Schell, G. (2001). Management Information Systems. London: Prentice Hall.

O`Brien, J. A. (2005). Introduction to Information Systems. (12 ${ }^{\text {th }}$ Edition). USA: McGraw-Hill.

Peter, J. P., dan Olson, J. C. (2003). Consumer Behavior and Marketing Strategy. Sixth Edition. New York: McGraw-Hill. 
Rayport, J. F., Jaworski, B. J. (2003). Introduction to E-Commerce. Second Edition. Mc Graw - Hill Education (Asia).

Scoot-ladd, B., and Noonan, J. (2012). Succession planning in family farm Business; Forum Manajemen Indonesia, 13 November 2012 Yogyakarta.

Shneiderman, B. (2005). Designing the User Interface: Strategies for Effective Human-Computer Interaction. 4th Edition. New York: Addison-Wesley.

Shukla, T. (2010). Factors Affecting 'Internet Marketing' Campaigns with Reference to Viral and Permission Marketing. IUP Journal of Management Research. Hyderabad, vol 9(1):26.

Sitinjak, J. R., Tumpal, dan Sugiarto. (2006). Lisrel. Cetakan Pertama. Yogyakarta: Graha Ilmu.

Sugiyono. (2007), Statistika Penelitian Bisnis. Cetakan Kesebelas. Jakarta: Alfabeta.

Turban, E., King, D: Lee Jae: Vichland, Dennis (2002). Electronic Commerce: a managerial perspective 2002 (International edition ). New Jersey: Pearson Prentice Hall.

Turban, Rainer, Potter. (2003). Introduction to Information Technology, 2nd Edition. USA: John Wiley \& Sons.

Vincent Gazpersz.(2003). Metode Analisis untuk Peningkatan Kualitas. PT. Gramedia Pustaka Utama. Jakarta. 